\title{
CONCEPT OF PUBLIC DIPLOMACY: LINGUISTIC APPROACH
}

\section{Sobolieva O.S.}

\section{INTRODUCTION}

Public diplomacy is a relatively new concept in scientific research. Its active study began only at the end of the XX century. Most scientific developments were carried out in the field of diplomacy, politics, foreign relations, mass communications, and the like. In recent decades, the concept "public diplomacy" has attracted the attention of linguists. According to many scholars, public diplomacy is information and communication technology, or the communication policy of state. This means that it is undoubtedly the subject of research in communicative linguistics, which studies the processes of communication between people using a living natural language and considering all available components of communication.

Public diplomacy (hereinafter PD) is one of the priority areas of research for Ukrainian scientists nowadays. There are a lot of arguments to support this idea. First, the urgent goal of Ukraine for the near future is to build a transparent democratic society, and one of the most effective tools in achieving this goal is PD, which is a recognized government soft power strategy. Secondly, an equally important task is to create a positive image of Ukraine abroad. This is recognized at the state level, in the program "Financial support for ensuring an international positive image of Ukraine, for ensuring the activities of the Ukrainian Institute, measures to support ties with the Ukrainians, living outside Ukraine" (2019). According to this program, "the goals of using budget funds are to improve understanding and perception of Ukraine and Ukrainians in the world, the formation of a positive international image of Ukraine and the popularization of Ukrainian culture and language abroad"1. This confirms that the importance of PD for Ukraine is recognized at the

\footnotetext{
${ }^{1}$ Порядок використання коштів, передбачених у державному бюджеті для реалізації заходів і проектів Українського інституту: Постанова від 12 червня 2019 p. № 638 // Кабінет Міністрів України. URL: https://zakon.rada.gov.ua/laws/show/511-2019-п (дата звернення 13.02.2021)
} 
highest state level. Thirdly, PD, which is communicative in its essence, undoubtedly has a linguistic component that determines its success and effectiveness. However, the analysis of the base of extended abstracts of dissertations presented in the National Library of Ukraine named after V. Vernadskyi showed that as of March 2021 there is not any scientific study of the linguistic aspect of PD. Thus, the relevance of the research topic is beyond doubt.

The analysis of foreign studies has also shown that the problems of PD have been researched mainly from the point of view of foreign policy, state image, international public relations etc. In the field of political science and international relations, very interesting studies have been carried out by such scientists as A. Tishchenko-Tishkovets (Ukraine; public diplomacy in the foreign policy system) $)^{2}$, N. Pipchenko (Ukraine; conceptual and structuralpolitical dimensions of virtual diplomacy) ${ }^{3}$, A. Manzhulina (Russia; US public diplomacy $)^{4}$, P.F. de Gouveia, H. Plumridge (UK; Developing EU Public Diplomacy Strategy) ${ }^{5}$, G. Szondi (UK; public diplomacy and national branding) ${ }^{6}$ and others. The linguistic component of public diplomacy is insufficiently developed, but there is still a number of studies devoted to certain aspects of public diplomacy in the field of philology, in particular: A. Oberemchenko (Russia; pragmalinguistic aspect of the speech behavior of a diplomat) ${ }^{7}, \mathrm{H}$. Trabelsi (Russia; linguo-communicative analysis of diplomatic discourse) ${ }^{8}$, S.B. Rasmussen (Spain; EU public diplomacy) ${ }^{9}$,

2 Тищенко-Тишковець О. М. Публічна дипломатія у системі зовнішньої політики : автореф. дис. ... канд. політ. наук : 23.00.03. Київ, 2011. 22 с.

${ }^{3}$ Піпченко Н. О. Концептуальні та структурно-політичні виміри віртуальної дипломатії : автореф. дис. ... канд. політ. наук : 23.00.03. Київ, 2008. 15 с.

${ }^{4}$ Манжулина О. А. Публичная дипломатия США : автореф. дис. ... канд. полит. наук : спец. 23.00.04. Санкт-Петербург, 2005. 24 с.

5 Gouveia P., Plumridge H. European Infopolitik : Developing EU Public Diplomacy Strategy. London, 2005. 60 p.

${ }^{6}$ Szondi G. Public diplomacy and nation branding: Conceptual similarities and differences. Netherlands Institute of International Relations "Clingendael”, 2008. 52 p.

7 Оберемченко Е. Ю. Прагмалингвистический аспект речевого поведения дипломата (на материале русского и немецкого языков) : автореф. дис. ... наук. степени канд. фил. наук : 10.02.19. Ростов-на-Дону, 2011. 23 с.

${ }^{8}$ Трабелси Х. Лингвокоммункативный анализ дипломатического дискурса : автореф. дис. ... канд. фил. наук : спец. 10.02.01. Москва, 2013. 22 с.

9 Rasmussen S. Discourse Analysis of EU Public Diplomacy Messages and Practices. Netherlands Institute of International Relations "Clingendael”, 2009. 33 p. 
A. Dolea (UK; public diplomacy as a constructed discourse of interaction) ${ }^{10}$, P.O. Sandrin, A.R. Hoffmann (Brazil; EU public diplomacy) ${ }^{11}$ and others.

It should be noted that the interpretation of PD concept largely depends on socio-cultural and linguo-cultural factors. Therefore it varies in different linguistic environments. It can be explained by the fact that PD is a form of reflection of political culture of an individual state, as well as one of the main tools for disseminating its values and ideals among the relevant target audiences. Despite certain developments in the field of PD research, many problems remain unexplored. So the purpose of this research is to study the linguistic aspect of PD concept in Englishspeaking countries and to propose its definition for application in linguistics and strategic communications. The English language was chosen because it contains the largest amount of illustrative material for determining the interpretations and connotations of PD concept, because it has been widespread in the USA and the UK since 1960s.

\section{Formation of the concept of "public diplomacy"}

Since 1960s PD has become a separate concept. Journalists, public and state figures, public organizations, and later scientists, offer their own definitions of this concept, expand its meaning, and actively use it in scientific and diplomatic spheres. Within research the most common and interesting definitions since 1960s until nowadays have been analysed. For the convenience of presenting the analysis results, each definition has a special designation in the form of an abbreviation, which consists of letters PD, the serial number of definition (numbers from 1 to 40), the country (USA or UK), year of its origin (1963-2019) and surname of author (if applicable) or source.

One of the first steps in introducing PD in the USA was the Fulbright Program. This educational grant program, which was initiated in 1946 by former US Senator J.W. Fulbright, was funded by the Department of State to strengthen cultural and academic ties between citizens of the USA and other countries. In 1961, the US Congress passed Public Law 87-256, which stated the goal of the Fulbright Program, which is similar to the goals of PD: "to increase mutual under-standing between the

${ }^{10}$ Dolea A. Public Diplomacy as Co-constructed Discourses of Engagement. The Handbook of Communication Engagement / K. Johnston \& M. Taylor (Eds.). Wiley-Blackwell, 2018. P. 331-345.

${ }^{11}$ Sandrin P., Hoffmann A. Silences and hierarchies in European Union Public Diplomacy. Revista Brasileira de Política Internacional, 2018. № 61. P. 1-18. 
people of the United States and the people of other countries by means of educational and cultural exchange; to strengthen the ties which unite us with other nations by demonstrating the educational and cultural interests, developments, and achievements of the people of the United States and other nations, and the contributions being made toward a peaceful and more fruitful life for people throughout the world; to promote international cooperation for educational and cultural advancement; and thus to assist in the development of friendly, sympathetic, and peaceful relations between the United States and the other countries of the world"12.

One of the first definitions was proposed in 1963 by E.R. Murrow, director of the US Information Agency (hereinafter USIA).

"Public diplomacy differs from traditional diplomacy in that it involves interaction not only with governments but primarily with nongovernmental individuals and organisations. Furthermore public diplomacy activities often present many differing views represented by private American individuals and organizations in addition to official government views, 13

(PD1-USA-1963/Murrow).

Since 1965, the previously widely used concept "propaganda" has become unacceptable for US foreign policy due to the accumulation of many negative connotations. Therefore, the USIA, headed by E.R. Murrow, got the status of the US legislative body in matters of international relations and introduced the PD concept in all aspects of its activities. E.R. Murrow proposed the following definition:

"Public diplomacy $<\ldots>$ deals with the influence of public attitudes on the formation and execution of foreign policies. It encompasses dimensions of international relations beyond traditional diplomacy; the cultivation by governments of public opinion in other countries; the interaction of private groups and interests in one country with another; the reporting of foreign affairs and its impact on policy; communication

${ }^{12}$ An act to provide for the improvement and strengthening of the international relations of the United States by promoting better mutual understanding among people of the world through educational and cultural exchanges / Public Law 87-256Sept. 21, 1961 URL: https://www.govinfo.gov/content/pkg/STATUTE75/pdf/STATUTE-75-Pg527.pdf\#page=11. (Retrieved 11.02.2021)

\footnotetext{
${ }^{13}$ Leonard M. Public Diplomacy. London, 2002. 185 p.
} 
between those whose job is communication, as diplomats and foreign correspondents; and the process of intercultural communications ${ }^{, 14}$.

(PD2-USA-1965/USIA).

In 1975, the Foreign Policy Commission on Government Reorganization, headed by Ambassador R. Murphy, conducted a study of PD. In the report of the Comptroller General of the United States (director of the Government Accountability Office, hereinafter GAO) to Congress on the Murphy Commission proposals, certain characteristics of PD were distinguished:

«US public diplomacy - international information, education, cultural relations» ${ }^{15}$.

Based on separation of information into political and general, it was suggested that

"the primary responsibility for articulating and advocating as well as formulating U.S. foreign policy is vested in the President and the Secretary of State". 16

The primary mission of the $\boldsymbol{U S I A}$ was defined as following

"has been and should remain that of giving wider resonance abroad to authoritative definitions and interpretations of U.S. policy under proper State Department guidance" ${ }^{, 17}$.

In addition, it was proposed to empower the USIA with the function of "advising policymakers on foreign public opinion $<\ldots>$ through cultural contacts and the media", and "responsible for domestic and international aspects of general information about the United States, educational and cultural programs" $" 18$.

Particular attention was paid to the Voice of America, which was to become an independent agency and act as a reliable, objective medium of information since it is of great importance to national interests

${ }^{14}$ Cull N. J. "Public Diplomacy" Before Gullion: The Evolution of a Phrase. USC Center on Public Diplomacy. URL: https://www.uscpublicdiplomacy.org. (Retrieved 15.12.2019)

15 Public Diplomacy in the Years Ahead - An Assessment of Proposals for Reorganization May 5 1977/ Report to the Congress by the Controller General of the United States. URL: https://books.google.com.ua. (Retrieved 07.12.2019)

16 Ibid.

17 Ibid.

18 Ibid. 
"how U.S. foreign policy is reported and advocated, especially by fast media and especially in moments of international crisis"19 (PD3-USA-1975/GAO).

In 1977, the PD concept was used in the U.S. Congress in the context of "Public Diplomacy and the Future" at a hearing before the Subcommittee on International Operations of the Committee on International Relations, House of Representatives. In the report of the Murphy Commission on the Organization of the Foreign Policy Apparatus, the following was noted:

"what is now referred to as "public diplomacy" is in reality an uneasy amalgam of three different and distinct activities: policy information, cultural communication and shortwave radio broadcasting ${ }^{, 20}$.

(PD4-USA-1977/U.S. Congress)

At the same time, F. Stanton (Chairman of U.S. Advisory Commission on Information) once again emphasized the need to substantiate the importance of PD based on the division of information into general and political.

... bringing a foreign people in touch with American culture involves transmitting information about culture $<\ldots>$ USIA defines culture very broadly to include all aspects of our domestic life as a nation and people. Culture includes $<\ldots>$ not only information about the arts, letters, education and science, but also information about the American economy, governmental system, and even the views of our citizens on international affairs ${ }^{21}$ (PD5-USA-1977/Stanton).

Political information is intended to interpret and defend the interests of U.S. foreign policy. The main difference between these two types of information is the ability to be controlled by the government (the government can control political information, while cannot control the general one). This distinction is widely used by authoritarian governments. But, given that America is a democratic state and promotes freedoms and equal rights for all, the advocacy and defence of foreign policy interests should be separated from the dissemination of values and ideals which American society is based on. During the hearing

${ }^{19}$ Public Diplomacy in the Years Ahead - An Assessment of Proposals for Reorganization May 5 1977/ Report to the Congress by the Controller General of the United States. URL: https://books.google.com.ua. (Retrieved 07.12.2019)

20 Ibid.

21 Ibid. 
P.A. Woodring drew attention to the need for a clear definition of PD concept. In her opinion, the concept had become very widely used, but no one offered its clearly formulated definition. According to P.A. Woodring

"Public diplomacy is an attitude and a process that shape the very nature of the way our Government conducts its international affairs. It encompasses a range of activities through which the U.S. Government influences and is influenced by publics abroad and at home in the formulation and implementation of $\boldsymbol{U}$.S. foreign policy. These activities include education on international issues; basic information programs; public relations activities; policy explanations; exchanges that bringing people together in a mutual learning experience; development of crosscultural appreciation; and taking into account public views in official actions, 22 .

\section{(PD6-USA-1977/Woodring)}

In 1987, the US Department of State issued Dictionary of International Relations Terms, which regulated the introduction of a new terminology base and proposed the following definition of PD

Refers to government-sponsored programs intended to inform or influence public opinion in other countries. The chief instruments of public diplomacy are publications, motion pictures, cultural exchanges, and radio and television. $<\ldots>$ The United States Information Agency is responsible for the U.S. Government's overseas in formation and cultural programs, including the Voice of America ${ }^{23}$.

\section{(PD7-USA-1987/ Dictionary of International Relations Terms)}

In 1990 H.N. Tuch, author of "Communicating with the World", defined PD as

" $<\ldots>$ a communication process of the government of a country with foreign audiences, trying to explain his ideas and ideals of respective nation, its institutions and its culture as well as national interests and policies, 24 .

(PD8-USA-1990/Tuch)

22 Public Diplomacy and the Future: Hearings Before the Subcommittee on International Operations of the Committee on International Relations. House of Representatives. Ninety-fifth Congress. First Session / U.S. Government Printing Office. 1977. URL: https://books.google.com.ua. (Retrieved 04.12.2019)

23 Dictionary of International Relations Terms. 1987. 115 p. URL: https://fas.org/irp/doddir/dod/jp1_02.pdf. (Retrieved 15.12.2019)

${ }^{24}$ Tuch H. Communicating with the World. New York, 1990. 244 p. 
Also in 1990, J. Nye in his book "Doomed to be leaders: the essence of American power is changing" offered a definition of PD concept based on the concept "soft power". He introduced the concept of "soft power" to denote

" $<\ldots>$ a nation's ability to attract and persuade. Whereas hard power - the ability to coerce - grows out of a country's military or economic might, soft power arises from the attractiveness of its culture, political ideals, and policies $" 25$.

According to J. Nye, both soft and hard power are determined by certain types of behaviour, basic means of treatment and government strategies (see Table 1).

Table 1

Characteristics of "soft power" and "hard power" by J. Nye $\mathrm{N}^{26}$

\begin{tabular}{|c|c|c|c|}
\hline Soft & Type of behaviour & $\begin{array}{c}\text { Means of } \\
\text { circulation }\end{array}$ & Government strategy \\
\hline Power & $\begin{array}{c}\text { attraction, } \\
\text { explanation of the } \\
\text { political vector }\end{array}$ & $\begin{array}{c}\text { values, culture, } \\
\text { politics, state } \\
\text { structure }\end{array}$ & $\begin{array}{c}\text { public diplomacy, } \\
\text { bilateral diplomacy, } \\
\text { multilateral } \\
\text { diplomacy }\end{array}$ \\
\hline $\begin{array}{c}\text { Hard } \\
\text { Power }\end{array}$ & $\begin{array}{c}\text { economic enticement } \\
\text { and pressure, } \\
\text { military coercion and } \\
\text { intimidation }\end{array}$ & $\begin{array}{c}\text { economic sanctions } \\
\text { and payments, } \\
\text { military strength and } \\
\text { threats }\end{array}$ & $\begin{array}{c}\text { financial assistance, } \\
\text { bribes, penalties, } \\
\text { coercive diplomacy, } \\
\text { war, alliance building }\end{array}$ \\
\hline
\end{tabular}

The lexical and semantic analysis of the above table allows to conclude that the concepts which are basic for "soft power" have positive connotations (for example, values, culture) and provide for free communication (for example, attraction, explanations, public / bilateral / multilateral diplomacy), whereas "hard power" is characterized by concepts with negative connotations (for example, sanctions, threats, bribes) and is aimed at subjugation (for example, enticement, coercion, intimidation).

J. Nye believes that the main functions of public diplomacy are the following

25 Nye J. Soft power. The means to success in world politics. New York, 2004. 208 p.

26 Ibid. 
Conveying information and selling a positive image is part of it, but public diplomacy also involves building long-term relationships that create an enabling environment for government policies ${ }^{27}$.

Today, information is power that is available to most of the world's population, and this leads to the "paradox of excess". Information overload leads to a lack of concentration and attention. In such conditions, the "winner" is the one who can highlight valuable information in the chaotic information field. In addition, in recent decades, the public has become more informed and cautious about propaganda. That is why reputation and trust are becoming the most important soft power resources. Modern public relations are based on the formation or vice versa destruction of the image of the state or society. In this sense, public diplomacy is becoming more effective than traditional, since it involves the participation of a wide range of participants in the communication process, namely the media, non-governmental organizations, corporations, intergovernmental associations, scientific and academic communities. If in a traditional society the winner was the one who had a more powerful army or economy, then in the information society the rules have changed. The winner in the argument is the one whose narrative wins. An example is the information confrontation between NATO and Serbia in 1999-2000 concerning the events in Kosovo that led to the overthrow of the Slobodan Milosevic regime. According to a nationwide survey conducted by the Institute of Social Sciences (University of Belgrade) in October 2000 which was commissioned by the Intermedia Survey Institute (Washington) $40 \%$ of adults of the Serbian population received information regarding elections and protests from the materials broadcasted by Radio Liberty (a private non-profit news and information medium; funded by the US Congress) and Voice of America (news and broadcast organization owned by the US Federal Government), while only $31 \%$ trusted the data provided by the state radio station Radio Belgrade ${ }^{28}$. It shows that trust plays a decisive role in modern international communications. So, public diplomacy, in contrast to propaganda, is based on trust, has more opportunities to create a narrative to form an attractive and positive image. Propaganda, which in traditional diplomacy was the main

27 Nye J. Soft power. The means to success in world politics. New York, 2004. 208 p.

${ }^{28}$ Kaufman E. A Broadcasting Strategy to Win Media Wars. The Washington Quarterly. 2002. № 25. P. 115-127. 
communication strategy of the government (and in some countries still remains the main one), on the contrary, creates a narrative that destroys trust and limits the possibilities for the formation of effective international relations.

J. Nye identifies three dimensions of PD, i.e. daily communication, strategic communication, and the development of relationships with key actors.

" $<\ldots>$ daily communications, which involves explaining the context of domestic and foreign policy decisions. After making decisions, government officials in modern democracies usually pay a good deal of attention to what to tell the press and how to do it. They generally focus on the domestic press - yet the foreign press corps has to be the most important target for the first dimension of public diplomacy. $\langle\ldots>$ involve preparation for dealing with crises and countering attacks $\langle\ldots>$ strategic communication, in which a set of simple themes is developed, much like what occurs in a political or advertising campaign. The campaign plans symbolic events and communications over the course of a year to brand the central themes, or to advance a particular government policy. $<\ldots>$ Special themes focus on particular policy initiatives $<\ldots>$ the development of lasting relationships with key individuals over many years through scholarships, exchanges, training, seminars, conferences, and access to media channels ${ }^{, 29}$ (PD9-USA-1990/Nye).

In 1992. B. Signitzer and T. Coombs argued that

"the purpose of public diplomacy is to exert an influence on attitudes of foreign audiences using persuasion and propaganda. Objectivity and truth are considered important tools of persuasion but not extolled as virtues in themselves. The tender-minded school argues that information and cultural programs must bypass current foreign policy goals to concentrate on the highest long-range national objectives. The goal is to create a climate of mutual understanding. Truth and veracity are considered essential, much more than a mere persuasion tactic" ${ }^{, 30}$.

\section{(PD10-USA-1992/Signitzer, Coombs)}

In 1995. J. Duffey, head of the US News Agency, speaking before Congress said:

29 Nye J. Soft power. The means to success in world politics. New York, 2004. 208 p.

${ }^{30}$ Snow N. Routledge handbook of public diplomacy. Routledge Handbook of Public Diplomacy/ edited by N. Snow and P.M. Taylor. Routlege, 2008. URL: https://www.researchgate.net/publication/322364170_Routledge_Handbook_of_Publ ic_Diplomacy. (Retrieved 07.12.2019) 
"Let me just say a word about public diplomacy. It is not public relations. It is not flakking for a Government agency or even flakking for America. It is trying to relate beyond government-to-government relationships the private institutions, the individuals, the long-term contact, the accurate understanding, the full range of perceptions of America to the rest of the world" ${ }^{\prime 31}$.

(PD11-USA-1995/Duffey)

In 1997 the USIA Integration Planning Group defined PD as following

"Public diplomacy seeks to promote the national interest and the national security of the United States through understanding, informing and influencing foreign publics and broadening dialogue between American citizens and institutions and their counterparts abroad" ${ }^{32}$.

(PD12-USA-1997/ USIA Integr.Plan. Group)

In 1999 the PD concept was interpreted by D. Welch (University of Kent, UK) as

"the deliberate attempt to influence the opinions of an audience through the transmission of ideas and values for the specific purpose, consciously designed to serve the interest of the propagandists and their political masters, either directly or indirectly",33 (PD13-UK-1999/Welch).

In November 2001, US Congressman H. Hyde said:

"the role that I would set for our public diplomacy, to enlist the populations of the world into a common cause and to convince them that the goals that they seek for themselves - freedom, security and prosperity - are the same as those the United States seeks" 34 (PD14USA-2001/Hyde).

${ }^{31}$ Snow N. Routledge handbook of public diplomacy. Routledge Handbook of Public Diplomacy/ edited by N. Snow and P.M. Taylor. Routlege, 2008. URL: https://www.researchgate.net/publication/322364170_Routledge_Handbook_of_Publ ic_Diplomacy. (Retrieved 07.12.2019)

${ }^{32}$ Trent D. Nontraditional U. S. Public Diplomacy : Past, Present, and Future. Washington, 2016. $312 \mathrm{p}$.

${ }^{33}$ Brown E., Morgan W., McGrath S. Education, Citizenship and New Public Diplomacy in the UK: What is Their Relationship? Citizenship, Social and Economics Education. 2009. URL: https://journals.sagepub.com/doi/abs/10.2304/ csee.2010.8.2.73 (Retrieved 12.12.2019)

${ }^{34}$ The message is America: rethinking U.S. public diplomacy / Committee on International Relations. House of Representatives. 2001. URL: http://commdocs.house.gov/committees/intlrel/hfa76189.000/hfa76189_0.HTM. (Retrieved 15.12.2019) 
At the same time, the State Secretary C. Powell defined the purpose of public diplomacy in an interesting formula:

"What are we doing? We're selling a product. That product we are selling is democracy" 35 (PD15-USA-2001/Powell).

In 2001 the supplementary report of the United States Advisory Commission on Public Diplomacy (hereinafter ACPD), defined PD as

" $<\ldots>$ the communication of U.S. interests and ideals beyond governments to foreign publics. <...> Public diplomacy is not just an accidental by-product of what is reported in the commercial media. Nor is it public affairs aimed at the American people. U.S. policymakers should and do promote their policies in the United States. Public diplomacy, however, is directed at publics abroad ${ }^{, 36}$.

(PD16-USA-2001/ ACPD)

In 2002, M. Butler, former UK Permanent Representative to the EU, noted that:

"The purpose of public diplomacy is to influence opinion in target countries to make it easier for the British Government, British companies or other British organisations to achieve their aims. The overall image of Britain in the country concerned is of great importance - but this is not to say that it is the only factor. The most important factor will usually be the actual policies of the British Government and the terms in which they are announced and explained by Ministers ${ }^{, 37}$.

(PD17-UK-2002/Butler)

In 2002 C. Ross (former United States diplomat) defined PD as following

"I conceive of public diplomacy as being the public face of traditional diplomacy. Traditional diplomacy seeks to advance the interests of the United States through private exchanges with foreign governments. Public diplomacy seeks to support traditional diplomacy by addressing non-governmental audiences, in addition to governmental audiences, both mass and elite. It works very much in coordination with and in parallel to the traditional diplomatic effort ${ }^{, 38}$.

35 Brand U.S.A. Foreign Policy. 2001. URL: www.jstor.org/stable/3183289 (Retrieved 15.12.2019)

${ }^{36}$ Public Diplomacy for the 21st century. Archive Site for State Department information prior to January 20, 2001. URL: http://web.archive.org/web/ 20010219045627/http://www.state.gov/r/adcompd/1995rep.html

(Retrieved 14.12.2019)

${ }^{37}$ Leonard M. Public Diplomacy. London, 2002. 185 p.

38 Ibid. 


\section{(PD18-USA-2002/Ross)}

In the same year, M. Leonard notes that the concept of

"the phrase 'public diplomacy' is often used as a euphemism for propaganda".

In his opinion, PD is about building relationships: understanding the needs of other countries, cultures and peoples, communicating their points of view; correcting misconceptions; searching for industries where you can find a common cause. At the same time, M. Leonard believes that the main difference between public and traditional diplomacy is that PD attracts a wider group of people from both sides and a wider range of interests that go beyond government interests. The scientist is convinced that PD is based on the premise that the country's image and reputation are public goods that can create a favourable or limiting environment for individual agreements in various fields. M. Leonard identified a hierarchy of actions that can be achieved by public diplomacy:

- Increasing people's familiarity with one's country (making them think about it, updating their images, turning around unfavourable opinions);

- Increasing people's appreciation of one's country (creating positive perceptions, getting others to see issues of global importance from the same perspective);

- Engaging people with one's country (strengthening ties - from education reform to scientific co-operation; encouraging people to see us as an attractive destination for tourism, study, distance learning; getting them to buy our products; getting to understand and subscribe to our values);

- Influencing people (getting companies to invest, publics to back our positions or politicians to turn to us as a favoured partner)" 39 .

(PD19-UK-2002/Leonard)

The 2003 report of the U.S. Advisory Group on PD for the Arab and Muslim World noted that

"Public diplomacy is the promotion of the national interest by informing, engaging, and influencing people around the world. Public diplomacy helped win the Cold War, and it has the potential to help win the war on terror",40.

${ }^{39}$ Leonard M. Public Diplomacy. London, 2002. 185 p.

${ }^{40}$ Djerejian E. Changing Minds Winning Peace. A new strategic direction for U.S. diplomacy in the Arab and Muslim world. Washington, 2003. 81 p. 


\section{(PD20-USA-2003/ U.S. Adv.Group on PD for Arab and Muslim World)}

U.S. General Accounting Office report (GAO, 2003) defines PD as following

"State's overall public diplomacy goal is to inform, engage, and influence global audiences. This goal is aimed at reaching out beyond foreign governments to promote better appreciation of the United States abroad, greater receptivity to U.S. policies among foreign publics, and sustained access and influence in important sectors of foreign societies. Public diplomacy is carried out through a wide range of programs that employ person-to-person contacts; print, broadcast, and electronic media; and other means ",41 (PD21-USA-2003/ GAO).

The Public Diplomacy Strategy Board (hereinafter PDSB, UK) which was established in 2003 defined public diplomacy as follows:

"Work which aims at influencing in a positive way, including through the creation of relationships and partnerships, the perceptions of individuals and organisations overseas about the $U K$ and their engagement with the UK, in support of HMG's overseas objectives ",42 (PD22-UK-2003/ PDSB).

In the same year, the international publishing house Macmillan Publishers issued The Diplomatic Dictionary (authors J. Berridge and E. James), according to which

"Not to be confused with open or parliamentary diplomacy, a latetwentieth-century term for propaganda conducted by diplomats",43.

(PD23-UK-2003/ Diplomatic Dictionary)

At the same time, P. van Ham wrote in his article "War, Lies, and Videotape: Public Diplomacy and the USA's War on Terrorism":

" $<\ldots>$ a key element of public diplomacy is the building of personal and institutional relationships and dialogue with foreign audiences by focusing on values, which sets the activity apart from classical diplomacy, which primary deals with issues" ${ }^{\text {"44 }}$.

(PD24-USA-2003/Ham)

41 U.S. Public Diplomacy: State Department Expands Efforts but Faces Significant Challenges. United States General Accounting Office, 2003. URL: https://www.gao.gov/new.items/d03951.pdf (Retrieved 16.12.2019)

42 Public Diplomacy Strategy Board. URL : https://www.dfat.gov.au/publicdiplomacy/public-diplomacy-strategy.html (Retrieved 15.10.2018)

${ }^{43}$ Berridge G., James A. A dictionary of diplomacy. New York, 2003. 297 p.

44 Ham P. War, lies, and videotape: Public diplomacy and the USA's war on terrorism. Security Dialogue, 2003. № 34. P. 427-444. 
Doctrine of Joint Psychological Operations (Joint Publication 3-53, 2003) proposed to define PD from the point of view of military experts:

"Those overt international public information activities of the United States Government designed to promote United States foreign policy objectives by seeking to understand, inform, and influence foreign audiences and opinion makers, and by broadening the dialogue between American citizens and institutions and their counterparts abroad",45 (PD25-USA-2003/ JP 3-53).

Interestingly enough is the opposite definition, which appeared in October 2003 in the New York Times, that is, a definition of what public diplomacy is not:

"United States public diplomacy is neither public nor diplomatic. First, the government - not the broader American public - has been the main messenger to a world that is mightily suspicious of it. Further, the State Department, which oversees most efforts, seems to view public diplomacy not as a dialogue but as a one-sided exercise. The result is America speaking at the world, usually with simplistic and often offensive propaganda ${ }^{, 46}$ (PD26-USA-2003/ NYT).

The above-mentioned C. Ross in his work "Public diplomacy comes of age" (2005) offered a slightly different definition:

"Yet, what is this art that people call public diplomacy? It is not traditional diplomacy, which consists essentially of the interactions that take place between governments. The practitioners of traditional diplomacy engage the representatives of foreign governments in order to advance the national interest articulated in their own government's strategic goals in international affairs. Public diplomacy, by contrast, engages carefully targeted sectors of foreign publics in order to develop support for those same strategic goals ${ }^{\text {"47. }}$.

(PD27-USA-2005/Ross)

In the same 2005, the American professor P. Sharp wrote the following

45 Doctrine for Joint Psychological Operations. Joint Publication 3-53. 2003. URL: $\quad$ https://nsarchive2.gwu.edu//NSAEBB/NSAEBB177/02_psyop-jp-3-53.pdf (Retrieved 14.12.2019)

${ }^{46}$ Holzman M. Washington's Sour Sales Pitch. The New York Times. 2003. P. 11-13.

47 Ross C. Public Diplomacy Comes of Age. The Washington Quarterly. 2002. URL: http://media.leeds.ac.uk/papers/pmt/exhibits/50/ross.pdf (Retrieved 12.12.2019) 
"Public diplomacy, the process by which direct relations are pursued with a country's people to advance the interests and extend the values of those being represented, appears to be an idea whose time has come, ${ }^{, 48}$.

\section{(PD28-USA-2005/Sharp)}

PD concept is associated with many ideas. In 2005, British scholar J. Melissen examines three of them: propaganda, nation branding and foreign cultural relations, noting that the first two concepts are

"Similar to public diplomacy, propaganda and nation-branding are about the communication of information and ideas to foreign publics with a view to changing their attitudes towards the originating country or reinforcing existing beliefs ${ }^{, 49}$ (PD29-UK-2005/Melissen).

The relationship between governments and foreign public opinion has traditionally been a hierarchical process focused on the dissemination of positive information. Lord P.R. Carter (UKб 2006) defines PD as:

" $<\ldots>$ work aiming to inform and engage individuals and organisations overseas, in order to improve understanding of and influence for the United Kingdom in a manner consistent with governmental medium and long term goals ${ }^{, 50}$.

\section{(PD30-UK-2006/Carter)}

British scientists E. Brown, W. Morgan and S. McGrath conduct an interesting study "Education, Citizenship and New Public Diplomacy in the UK: What is Their Relationship?" In their opinion, the aspect of global citizenship is the most relevant for the PD. Understanding and communicating with people from other countries and cultures is critical in a context in which all citizens are potential ambassadors ${ }^{51}$ so

"The so-called New Public Diplomacy, it is argued, is no longer the exclusive domain of professional diplomats. It is also about formal and informal encounters between ordinary citizens who can relate to and value one another. $\langle\ldots>$ It seems that the new public diplomacy is

${ }^{48}$ Melissen J. The New Public Diplomacy: Between Theory and Practice. Palgrave Macmillan, 2005. 246 p.

${ }^{49}$ Ibid.

${ }^{50}$ Public Diplomacy Third Report of Session 2005-06. House of Commons Foreign. Foreign Affairs Committee. 2006. URL: https://publications.parliament.uk/ $\mathrm{pa} / \mathrm{cm} 200506 / \mathrm{cmselect} / \mathrm{cmfaff} / 903 / 903$.pdf (Retrieved 16.12.2019)

${ }^{51}$ Brown E., Morgan W., McGrath S. Education, Citizenship and New Public Diplomacy in the UK: What is Their Relationship? Citizenship, Social and Economics Education. 2009. URL: https://journals.sagepub.com/doi/abs/10.2304/ csee.2010.8.2.73 (Retrieved 12.12.2019) 
moving closer to the notion of cultural relations and away from the role of propaganda and nation branding. International organizations and national governments, it is argued, need to acknowledge and understand this change if they are to influence a global public opinion. $<\ldots>$ Understanding and communicating with people from other countries and cultures is vital in a context in which all are potential ambassadors and where we are no longer represented just by our leaders. $<\ldots>$ This implies that children should be educated $<\ldots>$ to present their country in a good light whether at home or abroad"52.

(PD31-UK-2007/ Brown, Morgan, McGrath)

In 2007 P.B. Floyd, former Chief Deputy Assistant Secretary of Defence of the United States for public affairs, noted that:

"Public diplomacy is more about influencing foreign publics and broadening dialogue between American citizens and institutions and their counterparts abroad than it is about 'selling' a particular policy",53 (PD32-USA-2007/Floyd).

In 2008 former US diplomat J. Brown attempted to distinguish between propaganda and PD. As a result, he wrote:

"At its best, public diplomacy provides a truthful, factual exposition and explication of a nation's foreign policy and way of life to overseas audiences; encourages international understanding; listens and engages in dialogue; objectively displays national achievements overseas, including in the arts $"$ "54.

(PD33-USA-2008/Brown)

At the same time, he noted that PD achieves its goal through careful presentation of facts and argumentation. It appeals to the intellect and proves that its content and purpose are the same. Thanks to this, in his opinion, PD is honest, open and long-term.

52 Brown E., Morgan W., McGrath S. Education, Citizenship and New Public Diplomacy in the UK: What is Their Relationship? Citizenship, Social and Economics Education. 2009. URL: https://journals.sagepub.com/doi/abs/ 10.2304/csee.2010.8.2.73 (Retrieved 12.12.2019)

${ }^{53}$ Snow N. Routledge handbook of public diplomacy. Routledge Handbook of Public Diplomacy/ edited by N. Snow and P.M. Taylor. Routlege, 2008. URL: https://www.researchgate.net/publication/322364170_Routledge_Handbook_of_Publ ic_Diplomacy. (Retrieved 07.12.2019)

${ }^{4}$ Brown J. Public Diplomacy \& Propaganda : Their Differences. American Diplomacy. 2008. URL: http://americandiplomacy.web.unc.edu/2008/09/publicdiplomacy-propaganda-their-differences/ (Retrieved 16.12.2019) 
In the same year, the Department of Foreign and Commonwealth of Nations of Great Britain published a book devoted to the problems of PD "Engagement: Public Diplomacy in a Globalised World", which presents the views of leading scientists and officials. In particular, N. Cull, having analysed the history of the development of PD, identified some of its characteristics:

"(1) public diplomacy begins with listening $<\ldots>$ (2) public diplomacy must be connected to policy $<\ldots>$ (3) public diplomacy is not a performance for domestic consumption <...> (4) effective public diplomacy requires credibility, but that has implications $<\ldots>$ (5) sometimes the most credible voice is not one's own $<\ldots>$ (6) public diplomacy is not always "about you" < ..> (7) public diplomacy is everyone's business $", 55$.

In his opinion, propaganda and PD are connected in some way

"Like propaganda, public diplomacy is about 'influence'; but unlike propaganda, in public diplomacy influence is not necessarily a one-way street from the speaker to his or her target. At its best, public diplomacy is a two-way street: a process of mutual influence whereby a state (or other international player) facilitates engagement between publics or tunes its own policies to the map of foreign public opinion. In the ideal case, public diplomacy treats the foreign public as an active participant - not just as a flock of sheep waiting to be ideologically shorn ",56.

\section{(PD34-UK-2008/Cull)}

In 2010, British scholar, G. Berridge, very sceptical of PD in general, wrote:

"Public diplomacy' is the modern name for white propaganda directed chiefly at foreign publics" ${ }^{, 57}$.

According to the scientist, the propaganda directed abroad cannot be called "propaganda" by governments, since this term has long been associated with the systematic spread of lies. Therefore, there was a need for a euphemism. That is why the term "PD" has come to be used by many governments to refer to propaganda operations. Consequently, the term

" $<\ldots>$ had been hijacked to give propaganda cosmetic surgery and to facilitate a successful campaign in American bureaucratic politics" ${ }^{\circ 8}$.

55 Welsh J. Engagement: Public Diplomacy in a Globalised World. London, 2008. 172 p.

56 Ibid.

${ }^{57}$ Berridge G. Diplomacy. Theory and Practice. Palgrave Macmillan, 2010. 283 p.

58 Ibid. 


\section{(PD35-UK-2010/Berridge)}

In 2011, B. Gregory, in an article on US public diplomacy, wrote:

"Public diplomacy in the twentieth century was viewed as a statebased instrument used by foreign ministries and other government agencies to engage and persuade foreign publics for the purpose of influencing their governments. Today, public diplomacy has come to mean an instrument used by states, associations of states, and some substate and non-state actors to understand cultures, attitudes and behaviour; to build and manage relationships; and to influence thoughts and mobilize actions to advance their interests and values" ${ }^{\prime 59}$.

(PD36-USA-2011/Gregory)

In 2013 J. Melissen wrote in The Oxford Handbook of Modern Diplomacy that PD

" a metaphor for the democratization of diplomacy, with multiple actors playing a role in what was once an area restricted to a few" (PD37-UK-2013/Melissen).

In 2014, C. Ross formulated seven principles on which a holistic strategy of PD can be created to promote a national brand:

"1) policy advocacy $<\ldots>$ to ensure that foreign audiences understand $\boldsymbol{U} \boldsymbol{S}$ policies for what they are, not for what others say they are $<\ldots>$ 2) providing reasons and rationale - the context - for its policies $<\ldots>3$ ) international messages must be consistent, truthful, and credible $<\ldots>4$ ) to tailor messages for specific audiences $<\ldots>5$ ) to leverage our messages through all the communications channels at our command $\langle\ldots>6$ ) we need the strength of international alliances and private-sector partners, whether global corporations, humanitarian organizations, or US ex-patriot communities abroad $<\ldots>7$ ) build the foundations of trust and mutual understanding through a genuine commitment to dialogue" ${ }^{\text {"61 }}$ (PD38-USA-2014/Ross).

In 2016, the US Department of Defence in its dictionary of military and associated terms, which established the fourth standard of military terminology for the US Armed Forces, supplemented its previously proposed definition

59 Gregory B. American public diplomacy: Enduring characteristics, elusive transformation. The Hague Journal of Diplomacy. 2011. №6. P. 351-372.

${ }^{60}$ Cooper A., Heine J., Thakur R. The Oxford Handbook of Modern Diplomacy. Oxford, 2013. $766 \mathrm{p}$.

61 Ross C. Pillars of Public Diplomacy. University of Leeds. 2014. URL: http://media.leeds.ac.uk/papers/vp017ee0.html (Retrieved 17.12.2019) 
"Those overt international public information activities of the United States Government designed to promote United States foreign policy objectives by seeking to understand, inform, and influence foreign audiences and opinion makers, and by broadening the dialogue between American citizens and institutions and their counterparts abroad. In peace building, civilian agency efforts to promote an understanding of the reconstruction efforts, rule of law, and civic responsibility through public affairs and international public diplomacy operations" $"$ 2 .

\section{(PD39-USA-2016/ Dict.Military\&Associated Terms)}

According to the Encyclopaedia Britannica (2019):

"Public diplomacy, also called people's diplomacy, any of various government - sponsored efforts aimed at communicating directly with foreign publics. Public diplomacy includes all official efforts to convince targeted sectors of foreign opinion to support or tolerate a government's strategic objectives. Methods include statements by decision makers, purposeful campaigns conducted by government organizations dedicated to public diplomacy, and efforts to persuade international media to portray official policies favourably to foreign audiences" $" 63$.

According to the authors of the encyclopaedia, public diplomacy can be divided into two types: 1) branding or cultural communication; 2) political advocacy. The main idea of branding is

" $<\ldots>$ the government tries to improve its image without seeking support for any immediate policy objective. States use branding strategies to foster a better image of themselves in the world. Ideally, branding creates general goodwill and facilitates cooperation across a variety of issues" ${ }^{\prime \prime 4}$.

The second type, according to the developers of encyclopaedia, is political advocacy. Unlike branding,

" $<\ldots>$ political advocacy campaigns use public diplomacy to build foreign support for immediate policy objectives. Foreign publics may be

${ }^{62}$ Department of Defense Dictionary of Military And Associated Terms. Joint publication 1-02. 2016. URL: https://fas.org/irp/doddir/dod/jp1_02.pdf. (Retrieved 17.12.2019)

63 Public diplomacy. Definition, Types, Examples, \& Propaganda. Britannica.com. URL: https://www.britannica.com/topic/public-diplomacy (Retrieved 16.12.2019)

${ }^{64}$ Ibid. 
encouraged to support or oppose the leaders of other states $<\ldots>$,65 (PD40-UK-2019/Britannica).

Many definitions indicate that in XXI century in a globalized world, the role of PD has grown significantly. Therefore, Ukraine faced an urgent task to activate PD to increase the effectiveness of international activities and form a positive image of the country. This led to the fact that in the Military Doctrine of Ukraine (2015), PD is recognized as one of the communicative capabilities of the state, used within the framework of strategic communications. The doctrine notes that strategic communications mean the coordinated and proper use of the communicative capabilities of the state, namely PD, public relations, military relations, information and psychological operations, activities aimed at promoting the goals of the state ${ }^{66}$.

\section{Analysis of the concept "public diplomacy" based the theory of communications}

Based on the statement formulated in Military Doctrine (Ukraine, 2015 ) that "public diplomacy is one of the communicative capabilities of the state" ${ }^{\circ 7}$, the above mentioned definitions of PD in the English language were analysed based on communication theory proposed by G. Pocheptsov ${ }^{68}$ to formulate the characteristics of PD as a type of communication. To analyse the definitions, the following criteria were used: communicant, target audience, message, channel of communication, type of communication, purpose of communication. For the convenience of presenting the analysis results, each criterium has a special designation in the form of an abbreviation: communicator $(\mathbf{C})$, target audience (TA), message (M), channel of communication $(\mathbf{C C})$, purpose of communication (PC). The analysis results are presented in form of formulas created for each definition (e.g. C-TA-M-CC-PC).

65 Public diplomacy. Definition, Types, Examples, \& Propaganda. Britannica.com. URL: https://www.britannica.com/topic/public-diplomacy (Retrieved 16.12.2019)

66 Воєнна доктрина України: Рішення від 2 вересня 2015 року / Рада національної безпеки і оборони України. URL: https://www.president.gov.ua/ documents/5552015-19443 (Дата звернення 17.12.2019)

67 Воєнна доктрина України: Рішення від 2 вересня 2015 року / Рада національної безпеки і оборони України. URL: https://www.president.gov.ua/ documents/5552015-19443 (Дата звернення 17.12.2019)

${ }^{68}$ Почепцов Г. Теория комуникации. Київ, 2001. - 656 с. 
Missing criteria are indicated with *. (All criteria are indicated with bold italics in the text of definitions).

\section{PD1-USA-1963/Murrow - */TA/M/*/PC}

$C-$ not indicated

TA - governments, non-governmental individuals and organisations

M - views of private American individuals, organizations, official government views

$C C-$ not indicated

PC - interaction, presentation (of views)

PD2-USA-1965/USIA - C/TA/M/*/PC

C - governments, private groups, diplomats and foreign correspondents

TA - public opinion in other countries

$\mathbf{M}$ - foreign policies

$C C-$ not indicated

PC - influence, interaction, communication, intercultural communications

PD3-USA-1975/GAO - C/TA/M/CC/PC

C - USIA

TA - (public) abroad

$\mathbf{M}$-definitions and interpretations of U.S. foreign policy, domestic and international aspects of general information about the USA, educational and cultural programs

CC - cultural contacts, media (Voice of America)

PC - articulating, advocating, formulating foreign policy, giving resonance, advising policymakers

PD4-USA-1977/U.S. Congress - */*/*/CC/PC

$C$ - not indicated

$T A-$ not indicated

$M-$ not indicated

CC - cultural communication, broadcasting

PC - policy information, cultural communication

PD5-USA-1977/Stanton - */TA/M/*/PC

$C$ - not indicated

TA - foreign people

$\mathbf{M}$ - American culture

$C C-$ not indicated

PC - transmitting information

PD6-USA-1977/Woodring - C/TA/M/*/PC

C - U.S. Government 
TA - publics abroad and at home

$\mathbf{M}$ - U.S. foreign policy

$C C-$ not indicated

PC - influence, education, information, explanations, exchanges, development of cross-cultural appreciation

PD7-USA-1987/ Dictionary of International Relations Terms C/TA/*/CC/PC

C - government, USIA

TA - public opinion in other countries

$M-$ not indicated

CC - publications, motion pictures, cultural exchanges, radio, television

PC - to inform or influence

PD8-USA-1990/Tuch - C/TA/M/*/PC

C-government

TA - foreign audiences

M - ideas, ideals of a nation, its institutions, culture, national interests, policies

$\mathbf{C C}-$ not indicated

$\mathbf{P C}$ - to explain

PD9-USA-1990/Nye - C/TA/M/CC/PC

C-government officials

TA - foreign press corps (and with their help foreign public)

$\mathbf{M}$-domestic and foreign policy decisions, particular government policy

CC -press

PC - conveying information, selling a positive image, building longterm relationships, dealing with crises and countering attacks, political or advertising campaign, lasting relationships with key individuals

PD10-USA-1992/ Signitzer, Coombs - */TA/*/*/PC

$C-$ not indicated

TA - foreign audiences

$M$ - not indicated

$C C-$ not indicated

PC - persuasion, propaganda, to exert an influence, to create a climate of mutual understanding

PD11-USA-1995/Duffey - */TA/*/*/PC

$C-$ not indicated

TA - private institutions, individuals

$M-$ not indicated 
$C C-$ not indicated

PC -long-term contact, accurate understanding, full range of perceptions of America to the rest of the world

PD12-USA-1997/ USIA Integr.Plan. Group - C/TA/M/*/PC

C - American citizens and institutions

TA - foreign publics

$\mathbf{M}$ - national interest and the national security of the United States

$C C-$ not indicated

PC - understanding, informing and influencing, broadening dialogue

PD13-UK-1999/Welch - C/TA/M/*/PC

C - propagandists and their political masters

TA - audience

$\mathbf{M}$ - ideas and values

$C C-$ not indicated

PC - to influence, transmission of ideas and values

PD14-USA-2001/Hyde - */TA/M/*/PC

$C-$ not indicated

TA - populations of the world

$\mathbf{M}$ - goals of the United States, freedom, security and prosperity

$C C-$ not indicated

PC - to enlist into a common cause, to convince

PD15-USA-2001/Powell - C/*/*/*/PC

C - we (people of the USA)

TA - not indicated

$\mathbf{M}$ - democracy

$C C-$ not indicated

PC - selling a product

PD16-USA-2001/ ACPD - */TA/M/*/PC

$C-$ not indicated

TA - foreign publics / publics abroad

$\mathbf{M}$ - U.S. interests and ideals

$C C-$ not indicated

PC - communication

PD17-UK-2002/Butler - */TA/M/*/PC

$C-$ not indicated

TA - target countries

M - overall image of Britain, actual policies of the British Government, terms in which they are announced and explained by Ministers

$C C-$ not indicated 
PC - to influence opinion, to make it easier to achieve aims

PD18-USA-2002/Ross -*/TA/*/CC/PC

C-not indicated

TA - non-governmental audiences, governmental audiences, both mass and elite

$M-$ not indicated

$\mathbf{C C}$ - private exchanges

PC - addressing audiences

PD19-UK-2002/Leonard - */TA/*/*/PC

$C-$ not indicated

TA - people

$M-$ not indicated

$C C-$ not indicated

PC - propaganda, increasing familiarity, appreciation, engaging, influencing people

PD20-USA-2003/ U.S. Adv.Group on PD for Arab and Muslim World $-* / \mathbf{T A} / * / * / \mathbf{P C}$

$C-$ not indicated

TA - people around the world

$\boldsymbol{M}-$ not indicated

$\boldsymbol{C C}-$ not indicated

TC - informing, engaging, and influencing

PD21-USA-2003/ GAO - C/TA/M/CC/PC

C - state

TA - global audiences, foreign publics

M - U.S. policies

CC - person-to-person contacts; print, broadcast, electronic media; and other means

PC - to inform, engage, and influence, promote better appreciation, receptivity

PD22-UK-2003/ PDSB - */TA/*/*/PC

$C-$ not indicated

TA - individuals and organisations overseas

$M-$ not indicated

$C C-$ not indicated

PC - influencing perceptions about the UK, engagement with the UK, support of HMG's overseas objectives

\footnotetext{
PD23-UK-2003/ Diplomatic Dictionary - C/*/*/*/PC

C-diplomats

$T A-$ not indicated
} 
$M-$ not indicated

$C C-$ not indicated

$\mathbf{P C}$ - propaganda

PD24-USA-2003/Ham - */TA/M/*/PC

$C-$ not indicated

TA - foreign audiences

$\mathbf{M}$ - values

$C C-$ not indicated

PC - building of personal and institutional relationships and dialogue

PD25-USA-2003/ JP 3-53 - C/TA/M/*/PC

C - government, American citizens

TA - foreign audiences and opinion makers, institutions and citizens abroad

$\mathbf{M}$ - United States foreign policy

$C C-$ not indicated

PC - to promote objectives, seeking to understand, inform, and influence

PD26-USA-2003/ NYT - C/TA/*/*/PC

C-government

TA - world

$M-$ not indicated

$C C-$ not indicated

$\mathbf{P C}$ - propaganda

PD27-USA-2005/Ross - */TA/M/*/PC

$C-$ not indicated

TA -targeted sectors of foreign publics

$\mathbf{M}-$ government's strategic goals in international affairs

$C C-$ not indicated

PC - to develop support for strategic goals

PD28-USA-2005/Sharp - */TA/M/*/PC

$C-$ not indicated

TA - country's people

$\mathbf{M}$ - interests, values

$C C-$ not indicated

PC - to advance the interests, to extend the values

PD29-UK-2005/Melissen - */TA/M/*/PC

$C-$ not indicated

TA - foreign publics

$\mathbf{M}$ - information and ideas

$C C-$ not indicated 
PC - communication of information and ideas

PD30-UK-2006/Carter - */TA/*/*/PC

$C-$ not indicated

TA - individuals and organisations overseas

$M-$ not indicated

$C C-$ not indicated

PC - to inform and engage, to improve understanding and influence

PD31-UK-2007/ Brown, Morgan, McGrath - C/TA/*/CC/PC

C - ordinary citizens

TA - ordinary citizens, global public opinion, people from other countries and cultures

$M-$ not indicated

$\mathbf{C C}$ - formal and informal encounters

PC - understanding and communicating, to present their country in a good light whether at home or abroad

PD32-USA-2007/Floyd - C/TA/*/*/PC

$\mathbf{C}-$ American citizens and institutions

TA - citizens and institutions abroad, foreign publics

$M-$ not indicated

$C C-$ not indicated

PC - influencing foreign publics, broadening dialogue

PD33-USA-2008/Brown - */TA/M/*/PC

$C-$ not indicated

TA - overseas audiences

$\mathbf{M}$ - nation's foreign policy, way of life, national achievements

$C C-$ not indicated

PC - to provide exposition and explication, encourages international understanding; displays national achievements, listens and engages in dialogue

\section{PD34-UK-2008/Cull - C/TA/*/*/PC}

C - everyone, state, international player

TA - not for domestic consumption, foreign public

$M-$ not indicated

$C C-$ not indicated

PC - listening, mutual influence, engagement

PD35-UK-2010/Berridge - */TA/*/*/PC

$C-$ not indicated

TA - foreign publics

$M-n o t$ indicated

$C C-$ not indicated 
PC - white propaganda

PD36-USA-2011/Gregory - C/TA/M/*/PC

C - foreign ministries, government agencies, states, associations of states, and some sub-state and non-state actors

TA - foreign publics

$\mathbf{M}-$ cultures, attitudes and behaviour, interests and values

$C C-$ not indicated

PC - to persuade foreign publics, to understand cultures, attitudes and behaviour; to build and manage relationships; to influence thoughts and mobilize actions to advance their interests and values

PD37-UK-2013/Melissen - C/TA/*/*/PC

C - multiple actors

TA - multiple actors

$M-$ not indicated

$C C-$ not indicated

PC - democratization of diplomacy

PD38-USA-2014/Ross - */TA/M/CC/PC

$C-$ not indicated

TA - foreign audiences

$\mathbf{M}$ - US policies

$\mathbf{C C}$ - all the communications channels

PC - policy advocacy, providing context, mutual understanding, dialogue

\section{PD39-USA-2016/ Dict.Military\&Associated Terms -} $\mathrm{C} / \mathrm{TA} / * / \mathrm{CC} / \mathrm{PC}$

C - American citizens and institutions

TA - foreign audiences and opinion makers, citizens and institutions abroad

$M-$ not indicated

$\mathbf{C C}$ - public affairs, international public diplomacy operations

PC - to promote objectives, to understand, inform, and influence, to broaden the dialogue, to promote understanding, to foster a better image, to facilitate cooperation, to build foreign support

PD40-UK-2019/Britannica - C/TA/*/CC/PC

C-government organizations

TA - foreign publics, targeted sectors of foreign opinion

$M-$ not indicated

CC - communicating directly 
PC - to support or tolerate strategic objectives, to persuade international media to portray official policies favourably to foreign audiences, branding, political advocacy

The study analysed 40 definitions of PD in the English language proposed by scientists, politicians and government officials from the USA and the UK during 1963-2019 using criteria of communicative theory. Results of analysis are proposed below:

1. Out of $\mathbf{4 0}$ analysed definitions: $\mathbf{1 2}$ were proposed by British scientists and public figures, and $\mathbf{2 8}$ by American researchers and government officials. In terms of chronological characteristics, the first definitions of PD were created in the USA (since 1963). The first definition found in British sources dates to 1999. The data on the creation of official institutions responsible for PD in these countries can explain this fact: the $\boldsymbol{U S I A}$ (USA, 1953-1999) was created in 1953 and introduced the PD concept into all aspects of activity since 1963; the PDSB (UK, 2002-2006, successor of the Public Diplomacy Council) was created in 2002. Thus, the USA has been developing PD for over 60 years and, accordingly, has a rich base of sources for conducting linguistic research in this area.

2. The definitions were analysed based on five criteria of communicative theory. To present the analysis results each criterium was used in the form of an abbreviation, namely communicator (C), target audience (TA), message (M), channel of communication (CC), purpose of communication (PC), missing criteria were indicated with *. After analysis, each definition was presented in a form of formulae. All formulas were analysed using statistical methods. Out of $\mathbf{4 0}$ definitions of PD just 3 definitions (7.5\%) have full formula and define all 5 criteria (C/TA/M/CC/PC); these definitions were proposed by American scientist (J. Nye) and governmental agency (GAO). Other 36 definitions define from 4 to 2 criteria. The biggest number of definitions - $10(\mathbf{2 5 \%})$ indicate the same 3 criteria $(* / \mathbf{T A} / \mathbf{M} / * / \mathbf{P C})$. It means that mostly definitions do not indicate who is responsible of PD and which channel can be used to deliver message to target audience. Then 7 definitions $(\mathbf{1 7 . 5 \%})$ indicate the same 2 criteria $(* / \mathbf{T A} / * / * / \mathbf{P C})$, so they define just what must be said and who must get information. Then 7 definitions $\mathbf{( 1 7 . 5 \% )}$ indicate the same 4 criteria $(\mathbf{C} / \mathbf{T A} / \mathbf{M} / * / \mathbf{P C})$, it means that just a way of communicating message has not defined. Other 4 definitions (10\%) contain the same 4 criteria $(\mathbf{C} / \mathbf{T A} / * / \mathbf{C C} / \mathbf{P C})$, so they do not indicate which information can be considered as a message of PD. Out of remaining definitions $3(\mathbf{7 . 5 \%})$ indicate 3 criteria $(\mathbf{C} / \mathbf{T A} / * / * / \mathbf{P C}), 2$ 
(5\%) definitions indicate 2 criteria $(\mathbf{C} / * / * / * / \mathbf{P C})$, and 4 indicate varying combinations of criteria.

Each of above-mentioned criteria was analysed separately based on the frequency of its indication in definitions of PD. This analysis show that all 40 definitions indicate purpose of communication (PC); 37 definitions indicate target audience (TA); 21 definitions indicate message of public diplomacy (M); 20 definitions indicate communicator (C); and just $\mathbf{1 0}$ indicate channel of communication (CC). It means that defining the PD concept scientists and government officials are confident concerning its purpose (100\%) and mostly sure concerning the target audience of PD $(\mathbf{9 2 , 5 \%})$. At the same time just a half of scientists and government official pay attention to defining message of PD (52.5\%) and communicator $\mathbf{5 0 \%}$ ). What is more the way of communicating the message of PD, i.e. channel of communication, mostly is not defined just $\mathbf{2 5 \%}$ of scientists and government official indicate this criterium in their definitions.

3. Analysis of the definitions of PD by the criterion of "communicator" showed that in $\mathbf{2 0}$ definitions the communicant is not specified (of which $\mathbf{1 4}$ definitions are USA, 6 - UK). In the remaining 20 definitions, communicants are the following: government/government agency (e.g. USIA) (10 definitions - 25\%); citizens and institutions ( 5 definitions $-12.5 \%)$; state (3 definitions $\mathbf{7 . 5 \%}$ ); diplomats ( 2 definitions $-\mathbf{5 \%}$ ); people ( 2 definitions $-\mathbf{5 \%}$ ); correspondents (1 definition - $2.5 \%)$; private groups ( 1 definition $\mathbf{2 . 5 \%}$ ), propagandists and political masters (1 definition - 2.5\%); international player ( 1 definition $-2.5 \%$ ); sub-state and non-state actors (1 definition $-\mathbf{2 . 5 \%})$; multiple actors (1 definition $-\mathbf{2 . 5 \%}$ ).

4. Analysis of definitions by the criterium "target audience" showed that only $\mathbf{3}$ definitions do not indicate it. The target audience defined in other 37 definitions can be divided into certain groups: public opinion abroad/ foreign people/ foreign audiences 22 definitions (55\%); individuals and organisations overseas/institutions and citizens abroad (5 definitions - 12.5\%); populations of the world/ people around the world/ global audiences/ global public opinion (4 definitions - 10\%); non-governmental individuals and organisations/ private institutions, individuals (3 definitions $-7.5 \%$ ); target countries/ targeted sectors of foreign publics (3 definitions - 7.5\%); people/ country's people/ ordinary citizens (3 definitions $-7.5 \%$ ); governments ( 2 definitions $5 \%)$; publics home (1 definition - 2.5\%); foreign press corps (1 definition - 2.5\%); audience (1 definition - 2.5\%); world 
(1 definition $-2.5 \%)$; multiple actors (1 definition $-\mathbf{2 . 5 \%}$ ). This data show that mostly scientists and government officials consider that public diplomacy must be targeted at foreign audience at all (55\%) and they do not propose any specifications. Out of remaining definitions some specify foreign audience in some way $\mathbf{2 0 \%}$; individuals and organisations 5 definitions; target countries or sectors of foreign publics $\mathbf{- 3}$ ); while other define target audience globally $(\mathbf{1 2 . 5 \%}$; people around the world 4, world-1). Some definitions do not specify whether target audience must be foreign or domestic (15\%; non-governmental individuals and organisations $\mathbf{- 3}$; people $\mathbf{- 3}$ ). Just some definitions indicate specific target audience like governments $(\mathbf{5 \%})$, publics home $(\mathbf{2 . 5 \%})$, foreign press corps $(\mathbf{2 . 5 \%})$, multiple actors $(\mathbf{2 . 5 \%})$.

5. Analysis of definitions by the criterium "message" criterion showed that 19 definitions (47.5\%) do not contain such information at all. In the remaining 21 definitions $(\mathbf{5 2 . 5 \%})$, the purpose of public diplomacy can be defined in the following categories: ideas/ ideals/ values of nation ( 7 definitions $-17.5 \%$ ); foreign policies ( 6 definitions $-15 \%)$; national policies (4 definitions $-10 \%$ ); culture (3 definitions $7.5 \%)$; general information about country (2 definitions - 5\%); national interests ( 2 definitions - 5\%); government policy ( 2 definitions - 5\%); views of private American individuals and organizations (1 definition - 2.5\%); way of life (1 definition - 2.5\%); official government views (1 definition - 2.5\%); educational and cultural $p$ definition - 2.5\%rograms (1 definition - 2.5\%); national security (1 definition - 2.5\%); goals of nation (1 definition - 2.5\%); democracy (1 definition - 2.5\%); government's strategic goals in international affairs (1 definition - 2.5\%); public affairs and international public diplomacy operations (1 definition - 2.5\%). Analysis of this data show that mostly message of public diplomacy must contain policies $(\mathbf{3 0 \%})$ either foreign, national or government; ideas, ideals or values of nation

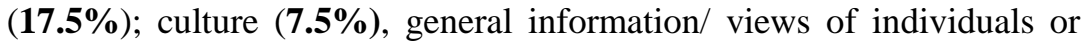
government/ goals national or strategic/ national interests (each per 5\%) as well as way of life, educational programs national security, democracy and public affairs (each per $2.5 \%$ )

6. Analysis of the definitions by the criterion "channel of communication" showed that $\mathbf{3 0}$ definitions (75\%) do not indicate any channel for delivering the message of PD. In remaining $\mathbf{1 0}$ definitions, the priority communication channels are the following media (4 definitions - 10\%); publications (3 definitions - 7.5\%); cultural contacts/ cultural communication ( 2 definitions - 5\%); private 
exchanges/ person-to-person contacts (2 definitions - 5\%); formal and informal encounters (1 definition - 2.5\%); all the communications channels (1 definition $\mathbf{- 2 . 5 \%}$ ). It should be noted that the criterium "channel of communication" is the least defined among other criteria. Whereas application of different kinds of media (media and broadcasting - 4 definitions; printed media $-\mathbf{3}$ definitions) is considered the most indicated channel of delivering the message of PD (17.5\%). Less indicated channels are cultural $(\mathbf{5 \%})$ or personal $(\mathbf{5 \%})$ communication; formal encounters $(\mathbf{2 . 5 \%})$ or all the communications channels $\mathbf{2 . 5 \%}$ ).

7. Analysis of the definitions by the criterium "purpose of communication" showed that all definitions (100\%) indicate the purpose of PD. But at the same time these purposes are various. Within the research the purposes were classified based on frequency of usage and based on the role of recipient (target audience). The most popular purposes of public diplomacy are influencing (42.5\% - 17 definitions), informing (30\% - 12 definitions) and understanding (25\% 12 definitions). Less popular are engaging (17.5\% - 7 definitions); broadening dialogue (15\% - 6 definitions); propaganda (12.5\% 5 definitions); facilitating (12.5\% - 5 definitions). Each of such purposes as communicating, building long-term relationships; persuading, promoting, or supporting 10\% (4 definitions per each purpose). Remaining definitions propose such purposes as advocating (7.5\%), interacting (5\%), presenting country (5\%), explaining (5\%), selling (5\%), listening (5\%). Also, there purposes as educating, transmitting, increasing and some others which are presented in just 1 definition and that is why do not considered. As for the role of recipient the purposes of public diplomacy can be divided into some groups: 1) where communicator is active but recipient can stay inert (such purposes as informing, presenting country, explaining, transmitting etc.); 2) where communicator is active and recipient is exposed to certain impact to behave in a specified way (such purposes as influencing, engaging, propaganda, persuading, selling, promoting); 3) where communicator and recipient take equal part in the process (such purposes as understanding, broadening dialogue, facilitating, communicating, building long-term relationships, interacting etc.).

\section{CONCLUSIONS}

Based on the assertion that public diplomacy is one of the communicative capabilities of the state, as it was formulated in Military Doctrine (Ukraine, 2015); as well as based on the results of the analysis 
of 40 definitions of public diplomacy, which were formulated by American and British scientists and government officials, a definition of public diplomacy was formulated. This definition was formulated within the concepts of communicative theory and indicate such criteria as communicator (C), target audience (TA), message (M), channel of communication (CC) and purpose of communication. The definition is proposed for application in linguistics and in strategic communications.

Public diplomacy is a communicative capability of state which is managed by a specialized institution and implemented by government, scientific, academic and cultural communities as well as by ordinary citizens (C) and aimed at a foreign or global audience (TA). The purpose of public diplomacy is to promote (PC) national interests and foreign policies of a country (M), to create a positive image and achieve mutual understanding (PC) by communicating ideas, ideals and values of nation as well as general information about country, culture and society $(\mathbf{M})$ through all communication channels, including but not limited to the media, interpersonal communication, public relations (CC).

\section{SUMMARY}

In modern society a relatively new concept of public diplomacy become more and more popular and relevant. The analysis of foreign studies showed that the problems of public diplomacy had been researched mainly within the fields of foreign policy, state image, international public relations etc. At the same time public diplomacy is information and communication technology and undoubtedly it can be the subject of research in communicative linguistics. It should be noted that the interpretation of the concept "public diplomacy" varies in different linguistic environments because it largely depends on sociocultural and linguo-cultural factors. The purpose of this research is to study the linguistic aspect of the concept "public diplomacy" in Englishspeaking countries and to propose its definition for application in linguistics and strategic communications. The English language has the largest amount of illustrative material for determining the interpretations and connotations of the concept of "public diplomacy", since this concept has been most popular and widespread in the USA and the UK since 1960s. The definitions proposed by American and British scientists and government officials were analysed based on five criteria of communicative theory, namely communicator, target audience, message, channel of communication, purpose of communication. 


\section{References}

1. An act to provide for the improvement and strengthening of the international relations of the United States by promoting better mutual understanding among people of the world through educational and cultural exchanges / Public Law 87-256-Sept. 21, 1961 URL: https://www.govinfo.gov/content/pkg/STATUTE-75/pdf/STATUTE-75Pg527.pdf\#page=11. (Retrieved 11.02.2021)

2. Berridge G., James A. A dictionary of diplomacy. New York, 2003. $297 \mathrm{p}$.

3. Berridge G. Diplomacy. Theory and Practice. Palgrave Macmillan, 2010. 283 p.

4. Brand

U.S.A.

Foreign

Policy.

2001.

URL: www.jstor.org/stable/3183289 (Retrieved 15.12.2019)

5. Brown E., Morgan W., McGrath S. Education, Citizenship and New Public Diplomacy in the UK: What is Their Relationship? Citizenship, Social and Economics Education. 2009. URL: https://journals.sagepub.com/doi/abs/10.2304/csee.2010.8.2.73 (Retrieved 12.12.2019) DOI 10.2304/csee.2010.8.2.73

6. Brown J. Public Diplomacy \& Propaganda: Their Differences. American Diplomacy. $2008 . \quad$ URL: http://americandiplomacy.web.unc.edu/2008/09/public-diplomacypropaganda-their-differences/ (Retrieved 16.12.2019)

7. Cooper A., Heine J., Thakur R. The Oxford Handbook of Modern Diplomacy. Oxford, 2013. 766 p. DOI 10.1093/oxfordhb/9780199548453.003.0021

8. Cull N. J. "Public Diplomacy" Before Gullion: The Evolution of a Phrase. USC Center on Public Diplomacy. URL: https://www.uscpublicdiplomacy.org. (Retrieved 15.12.2019)

9. Department of Defense Dictionary of Military And Associated Terms. Joint publication 2016. URL: https://fas.org/irp/doddir/dod/jp1_02.pdf. (Retrieved 17.12.2019)

10.Dictionary of International Relations Terms. 1987. 115 p. URL https://fas.org/irp/doddir/dod/jp1_02.pdf. (Retrieved 15.12.2019)

11.Djerejian E. Changing Minds Winning Peace. A new strategic direction for U.S. diplomacy in the Arab and Muslim world. Washington, 2003. $81 \mathrm{p}$.

12.Doctrine for Joint Psychological Operations. Joint Publication 3-53. 2003. URL: https://nsarchive2.gwu.edu//NSAEBB/ NSAEBB177/02_psyop-jp-3-53.pdf (Retrieved 14.12.2019) 
13. Dolea A. Public Diplomacy as Co-constructed Discourses of Engagement. The Handbook of Communication Engagement / K. Johnston \& M. Taylor (Eds.). Wiley-Blackwell, 2018. P. 331-345. DOI 10.1002/9781119167600.ch22

14. Gouveia P., Plumridge H. European Infopolitik : Developing EU Public Diplomacy Strategy. London, 2005. 60 p.

15. Gregory B. American public diplomacy: Enduring characteristics, elusive transformation. The Hague Journal of Diplomacy. 2011. № 6. P. 351-372. DOI 10.1163/9789004214149_008

16. Ham P. War, lies, and videotape: Public diplomacy and the USA's war on terrorism. Security Dialogue, 2003. № 34. P. 427-444. DOI 10.1177/0967010603344004

17.Hess S., Kalb M. The Media and the War on Terrorism. New York, 2003. 307 p.

18. Holzman M. Washington's Sour Sales Pitch. New York Times. 2003. P. 11-13.

19. Kaufman E. A Broadcasting Strategy to Win Media Wars. The Washington Quarterly. 2002. № 25. P. 115-127. DOI 10.1162/01636600252820171

20.Leonard M. Public Diplomacy. London, 2002. 185 p. DOI 10.18356/b9852088-en

21. Melissen J. The New Public Diplomacy: Between Theory and Practice. Palgrave Macmillan, 2005. 246 p. DOI 10.1057/9780230554931_1

22. Nye J. Soft power. The means to success in world politics. New York, 2004. 208 p.

23. Public diplomacy. Definition, Types, Examples, \& Propaganda. Britannica.com. URL: https://www.britannica.com/topic/publicdiplomacy (Retrieved 16.12.2019)

24.Public Diplomacy and the Future: Hearings Before the Subcommittee on International Operations of the Committee on International Relations. House of Representatives. Ninety-fifth Congress. First Session / U.S. Government Printing Office. 1977. URL: https://books.google.com.ua. (Retrieved 04.12.2019)

25.Public Diplomacy for the 21st century. Archive Site for State Department information prior to January 20, 2001. URL: http://web.archive.org/web/20010219045627/http://www.state.gov/r/adc ompd/1995rep.html (Retrieved 14.12.2019) 
26.Public Diplomacy Strategy Board. URL : https://www.dfat.gov.au/public-diplomacy/public-diplomacystrategy.html (Retrieved 15.10.2018)

27.Public Diplomacy Third Report of Session 2005-06. House of Commons Foreign. Foreign Affairs Committee. 2006. URL: https://publications.parliament.uk/pa/cm200506/cmselect/cmfaff/903/90 3.pdf (Retrieved 16.12.2019)

28. Rasmussen S. Discourse Analysis of EU Public Diplomacy Messages and Practices. Netherlands Institute of International Relations "Clingendael", 2009. 33 p.

29.Public Diplomacy in the Years Ahead - An Assessment of Proposals for Reorganization May 5 1977/ Report to the Congress by the Controller General of the United States. URL: https://books.google.com.ua. (Retrieved 07.12.2019)

30. Ross C. Pillars of Public Diplomacy. University of Leeds. 2014. URL: http://media.leeds.ac.uk/papers/vp017ee0.html (Retrieved 17.12.2019)

31.Ross C. Public Diplomacy Comes of Age. The Washington Quarterly. 2002. URL: http://media.leeds.ac.uk/papers/pmt/exhibits/ 50/ross.pdf (Retrieved 12.12.2019) DOI 10.1162/01636600252820144

32.Sandrin P., Hoffmann A. Silences and hierarchies in European Union Public Diplomacy. Revista Brasileira de Politica Internacional, 2018. №61. P. 1-18. DOI 10.1590/0034-7329201800111

33. Snow N. Routledge handbook of public diplomacy. Routledge Handbook of Public Diplomacy/ edited by N. Snow and P.M. Taylor. Routlege, 2008. URL: https://www.researchgate.net/publication/ 322364170_Routledge_Handbook_of_Public_Diplomacy. (Retrieved 07.12.2019) DOI 10.4324/9780203891520

34. Szondi G. Public diplomacy and nation branding: Conceptual similarities and differences. Netherlands Institute of International Relations "Clingendael”, 2008. 52 p.

35. The message is America: rethinking U.S. public diplomacy / Committee on International Relations. House of Representatives. 2001. URL: http://commdocs.house.gov/committees/intlrel/hfa76189.000/ hfa76189_0.HTM. (Retrieved 15.12.2019)

36. Trent D. Nontraditional U. S. Public Diplomacy : Past, Present, and Future. Washington, 2016. 312 p.

37. Tuch H. Communicating with the World. New York, 1990. 244 p. DOI 10.1007/978-1-349-60512-5 
38.U.S. Public Diplomacy: State Department Expands Efforts but Faces Significant Challenges. United States General Accounting Office, 2003. URL: https://www.gao.gov/new.items/d03951.pdf (Retrieved 16.12.2019)

39. Welsh J. Engagement: Public Diplomacy in a Globalised World. London, 2008. $172 \mathrm{p}$.

40. Воєнна доктрина України: Рішення від 2 вересня 2015 року / Рада національної безпеки i оборони України. URL: https://www.president.gov.ua/documents/5552015-19443 (Дата звернення 17.12.2019)

41. Манжулина О. А. Публичная дипломатия США : автореф. дис. ... канд. полит. наук : спец. 23.00.04. Санкт-Петербург, 2005. 24 с.

42. Оберемченко Е. Ю. Прагмалингвистический аспект речевого поведения дипломата (на материале русского и немецкого языков) : автореф. дис. ... наук. степени канд. фил. наук : 10.02.19. Ростов-наДону, 2011. 23 с.

43. Піпченко Н. О. Концептуальні та структурно-політичні виміри віртуальної дипломатії : автореф. дис. ... канд. політ. наук : 23.00.03. Київ, 2008. 15 с.

44.Порядок використання коштів, передбачених у державному бюджеті для реалізації заходів і проектів Українського інституту: Постанова від 12 червня 2019 р. № 638 // Кабінет Міністрів України. URL: https://zakon.rada.gov.ua/laws/show/511-2019-п (дата звернення 13.02.2021)

45. Почепцов Г. Теория комуникации. Київ, 2001. - 656 с.

46. Тищенко-Тишковець О. М. Публічна дипломатія у системі зовнішньої політики : автореф. дис. ... канд. політ. наук : 23.00.03. Київ, 2011. 22 с.

47.Трабелси X. Лингвокоммункативный анализ дипломатического дискурса : автореф. дис. ... канд. фил. наук : спец. 10.02.01. Москва, 2013. 22 с.

\section{Information about the author: Sobolieva Olena Serhiivna,}

Candidate of Pedagogical Sciences, Associate Professor, Associate Professor at the Department of Theory and Practice of Translation National Academy of Security Service of Ukraine 22, Maksymovycha str., Kyiv, 03022, Ukraine 